\title{
The study of the consumption process with a prominence of behavioral approach and its influence on the business units
}

\author{
Umer Qadir Sofi ${ }^{1}$ \\ University of Latvia ${ }^{1}$ \\ Corresponding author email: infoumersofi@gmail.com
}

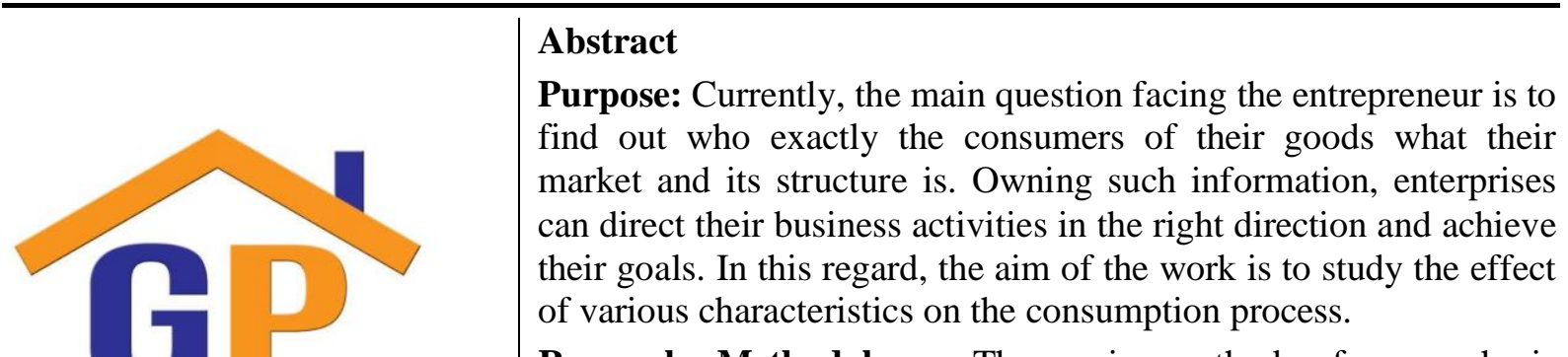

Research Methodology: The main method of research is monographic, and within the framework of the work a survey withheld conducted.

\section{Article History}

Received on 12 August 2019

Accepted on 7 November 2019
Results: The main results of the study are related to the fact that the characteristics of the consumption process have a significant impact on the activities of business units.

Keywords: Consumer process, Characteristics, Consumer groups

How to cite: Sofi, U. Q. (2019). The study of the consumption process with a prominence of behavioral approach and its influence on the business units. International Journal of Financial,

Accounting, and Management, 1(1), 57-68.

https://doi.org/10.35912/ijfam.v1i1.79

\section{Introduction}

In modern companies, marketing strategy is central, along with product strategy and personnel strategy. Business has mastered quite well the topic of modeling consumer behavior, rightly regarding it as the key to the formation of effective marketing decisions. Forming a marketing strategy is traditionally based on "three pillars": analysis of the market and competitors; analysis of the product, its capabilities and characteristics; analysis of the target audience, its socio-demographic features, lifestyles, consumption patterns. At the same time, consumption patterns that distinguish the target audience of a product, as if enlivening all the research foundations of a marketing strategy, make it possible to predict the success of a product in the market, determine the range of consumer reactions to certain marketing incentives, as well as topics and directions for such stimulation.

The sociology of consumption provides marketers with extensive theoretical material for modeling consumer behavior. A number of cult figures of social studies of the 19th - 20th centuries addressed the consumption study. - T. Veblen (the theory of demonstrative consumption), M. Weber (the concept of status groups and Protestant ethics), V. Zombart (the concept of luxury), G. Simmel, K. Marx, and others. (Marx K., 2000; Veblen T., 1953) It is significant that it was at the turn of the century (1902) that American universities first began to teach marketing. The study of consumer behavior became mandatory in business schools only in the mid-twentieth century, when scientific and technological progress, the commodity boom and the rapid development of consumer society formed a whole repertoire of consumer behavior, which led marketers to move away from the "economic man" 
stereotypes (Mitchell, W. C., 1910) and take a look henceforth for a heterogeneous target audience with different eyes, given the struggle for loyal demand.

The main method of research is monographic, and within the framework of the work a survey will be conducted. The main results of the study are related to the fact that the characteristics of the consumption process have a significant impact on the activities of business units. General and basic literature, periodicals, materials published on the Internet, and other available resources serve as a research base for research writing.

\section{Research Results and Discussion}

\section{Theoretical characteristics of factors and models influencing the consumer behavior}

As a first factor influencing consumer behavior, one can single out the infrastructure of a megacity concentrating various objects of the consumer market in a limited area. The development of the city depends on the rate of turnover in the consumer market; therefore, each subject of the urban infrastructure is interested in stimulating consumer behavior and directly or indirectly influences it. The growth of the consumer market and the service sector determines the main trend in the dynamics of the city - deindustrialization of megacities (which is most vividly observed in the number of large cities), changing the social composition of the city and social relations. (Ahmed, A. I., Uddin, M., 2004)

It may be noted the active development of not only retail outlets, but also places of selling pleasure and entertainment, that is, infrastructure of leisure and entertainment. There is a mixture of different forms of spending free time. For example, the format of retail stores - an entertainment mall. In addition to the galleries of shops and offices of domestic services, there are cafes and restaurants, skating rinks, bowling, multiplexes (multiplex cinemas). As a result, sales in shopping centers significantly exceed the performance of objects deprived of a leisure zone. (Timothy, D. J., 2005)

Since all these institutions (cinemas, malls etc.) require their filling and conduct their own campaign programs, instilling active leisure time outside the house, in the end, a synergistic effect is achieved on introducing the priority importance of leisure in the life of a city dweller. It can be said that the increasing role of leisure in the city is the second factor enhancing consumer behavior.

The third factor that stimulates consumer behavior is the commercialization and rationalization of urban life, which involves reciprocal payments in almost any acts of consumer behavior, and therefore participants in the process are interested in stimulating it in various ways.

In the city, the frequency of interactions replaces the depth of relationships. As a result, people's relationships are formalized, depersonalized, traditional social ties are destroyed, a feeling of anonymous freedom arises. The degradation of social ties and the change in the value system, primarily the orientation towards individualism and personal comfort, can be identified as the fourth factor determining the intensity of consumer behavior.

According to various sources, single people spend 20-30\% more on food, clothing and care products, and medicines more than family food. Non-family members are more socially active, spending more money on entertainment. According to analysts of European marketing companies, in the near future, citizens who are not burdened with families annually will buy $7 \%$ more. Therefore, propaganda idle life is conducted in different ways. Many positive images of bachelors are shown in advertisements. (Roszkowska-Hołysz, D., 2013)

Weakening social control can manifest itself not only in the loss of morality and deviant behavior (which causes an increase in egoism, an orientation towards personal needs), but in the expression of one's own individuality and in creativity (Krohn, M. D., Massey, J. L., 1980). Such freedom of selfrealization gives a chance to get out of "one's circle", the social environment and increases the social mobility of the urban population, which is reinforced by the infrastructure of the city. Therefore, the fifth factor can be considered the social mobility of the metropolitan population, which determines the activity of consumption.

The democracy of the trading floors and lending operations allows the acquisition of prestige goods, even for people who do not have adequate income. The autonomy of life, anonymity, the declared maximum democracy - the opportunity to try on any masks and images (even not always financially supported by material means) stimulates consumption. Example: credit card advertising, where elite items and a concert ticket are bought on credit by a lady of uncertain status for the 
"priceless first date." This conclusion can be seen in the results of a longitudinal study of the "middle cities" of the United States conducted by the staff of the University of Virginia. The reports of T. Caplow, G. Bar, and B. Chadwick said that modernization had destroyed class barriers. Instead of class polarization, class diffusion has begun. (Bahr, H. M., Chadwick, B. A., 1985)

The density of the population of the city facilitates imitation and rapid internalization of new ideas, behaviors, stylistic decisions, that is, fashion trends, makes it easy to adopt various trends, primarily in the field of consumption. The presence of public spaces that are socially indifferent (shopping malls, highways, squares, parks, coffee shops) allow a city dweller to personally meet (though not communicate) with "opinion leaders" - "trendsetters". The institution of public persons of "media persons", the so-called celebrities, the main translators of new products, contributes to the introduction of new trends. In ancient Greek mythology, the megalopolis was understood as a "city of great ideas"; today they talk more often about the "city of great people." There is a special term in the marketing "trend setter" - introducing trends. This institution can exist only in a large city concentrating such persons, creating conditions for their existence and a certain structure of their financing. "Presentation of oneself in everyday life" is the main way of human existence in the unfamiliar world of a city, "states I. Hoffman. (Jensen, O. B., 2006) Therefore, active consumption as a form of self-presentation is an integral part of the life of a citizen. The frequency of contacts, the ease of imitation, the presence of the institution of trendsetters (the system for introducing new products through popular people and special media) can be combined into the sixth factor that stimulates consumption, calling it "the specificity of society".

The equipment of persons with technical means of communication, that is, the "radio-magnetic information environment" and access to the media, also creates additional opportunities for influencing consumer behavior, which can be considered the eighth factor. Moreover, now in the media, from the point of view of domestic and foreign authors, the economic and stimulating consumption function is dominant, and not educational or educational. Commercial information is mixed with socially significant, and the average reader can not always identify it.

The technical equipment and openness of modern communication systems (not just technical ones) allow any person to enter into it and create their own "community", that is, their own communicative structure. This leads to fragmentation, fragmentation of the communicative urban environment, to its transformations (one of the reasons for the large number of subcultures in densely populated cities). The openness of communicative systems is also used by commercial companies, introducing the product into social networks, creating forums, blogs, communities, and thereby stimulating consumption.

On the other hand, a person constantly has to migrate from one environment to another, change different communities (and communication structures), and, consequently, some formal elements (for example, the presence of some accessories or clothes) that generate new needs and stimulate consumer behavior. Thus, the variability of communicative formats (or different societies with which a person has to interact and adapt accordingly) is the ninth factor causing the intensity of consumer behavior.

Increased information pressure provides a visual environment of cities, which is the tenth factor. "Design and disciplines that study environment can be considered as one of the branches of mass communication," says J. Baudrillard (Baudrillard, J., Levin, C., 1981). This allows us to consider the images of urban objects (shops, restaurants, cinemas, leisure centers) a means of communication. Signs, showcases, outdoor advertising, advertising on transport, promoters in points of active communications represent a huge arsenal of tools that set the program of possible actions in the field of consumption.

The influence of international trends can be singled out as the twelfth factor. Large cities strive to develop international contacts, including tourism, creating a special infrastructure (transport, hotels, orientation systems, shops, catering and recreation points), adapting many urban elements to international standards.

The desire to integrate with the international community is manifested in the unification of the information space. Naturally, it is necessary to mention the role of the Internet in the processes of internationalization, the provision of access to this resource was mentioned above. Since residents of 
large cities consume information more intensively, this unified pressure is felt precisely in the environment of densely populated cities.

The consequence of the urbanization process, which is characterized by increased density and heterogeneity of the population of the metropolis, fragmentation, declassification, population mobility, the formation of open communication systems, is not only an increase in the diversity of forms and number of impacts on the resident, but also the emergence of complex social technologies that intensify consumer behavior.

The urban environment, including the material, industrial and social infrastructure of the city, its communications, social interactions, becomes a special social technology of managerial impact on consumer behavior, since consumption is stimulated purposefully in the interests of certain structures. It is through the organization of space that the state exercises social control. By redistributing budgets and issuing permits, the government regulates the development of certain territorial units (creation of shopping centers, elite residential development, clinics, highways, communications), forms the transport, social, communication / information infrastructure. The creation of the "right" infrastructure is ensured by private capital, which is in the system of constant monetary circulation, which implies an increase in the production of a product (product or service) and a corresponding increase in consumption. Planning and urban development are controlled by big business.

Intensification of consumer behavior leads to negative social consequences associated with transformations in the value system, aggravating conflicts in society and destructuring the system of social relations. According to Kim et al., values and norms of predecessors become inadequate to the present and seem useless in the future, which exacerbates the natural contradictions between the generations and aggravates the spiritual confrontation between them, stimulating the conflict (Kim, $\mathrm{H}$. K., Pears, K. C., Capaldi, D. M., Owen, L. D., 2009).

Unfortunately, these global problems of exploitation of consumer behavior by certain structures, its unrestrained intensification for the sake of gaining benefits and at the same time without regard to the emerging general socio-ecological and spiritual problems, encouraged by a corrupt state, are obviously not solvable. On the contrary, the state sees another means of controlling the masses, immersing them in an environment of unrestrained consumption and distracting them from creative, socially active and political life. It turns out that even social policy in an economic-centered state and the commercialization of all ways of meeting these needs will be focused on stimulating consumption as such, without taking into account its social consequences.

As for consumer behavior models, in the middle of the twentieth century, it became clear that in modeling consumer behavior there are not and cannot be definitive truths and schemes: these models develop together with the consumer society. A modern person is often not just a consumer, he is an experienced consumer who has reasonable mental pictures of most product categories, unique attachments to brands and brands. At the same time, this is a developing consumer: his choice and attachments are not something forever given, motives are mobile, loyalty is conditional, the pattern of actions can change radically and quickly. Like modern consumption, which, according to Baudrillard (Baudrillard, J., 2016, Baudrillard, J., 2001), is an ideal practice that does not know saturation, and sociology's ideas about consumer behavior are far from complete. As a rule, marketers reduce all existing theories about consumer behavior into several basic models with which you can work in the practice of the company. It all started with two models ("rational" and "irrational" consumer), today there are six such models. What can be the basis for determining models of consumer behavior?

The eternal question of the consumer society "Who determines the actual needs of the market - the manufacturer or the consumer?" today is usually solved in favor of the manufacturer of goods or services. Initially, it was assumed that all goods and services on the market are the answer to the real needs and requirements of individual and corporate buyers, consumers are simply looking for the best (optimal) answer for this abundant supply. In the conditions of a shortage of goods, the manufacturer is practically not faced with the problem of special efforts to mobilize demand. In the conditions of total deficit, there is rather another problem, when the consumer, if funds allow, is ready to buy for the future even what he does not need here and now. In such a situation, it is enough for the manufacturer to simply meet the real needs of consumers already existing in the market with their goods or services, but this does not mean full control of demand. According to classical economic theory, market relations, as the situation of deficit is resolved, lead to the realization of a transparent formula 
"demand controls supply," while a person is rational in his consumer behavior, and his needs are reasoned and reasonable.

At the dawn of the consumer society, it was still possible to say that the demand or desires of consumers control the behavior of producers, forcing them to expand production or create new products that meet the rational needs. However, in the consumer society, as markets develop, there is a shortage not of goods, but of demand. Existing companies in the ideology of growth and competition with the help of marketing technologies are forced to solve a whole range of tasks: 1) retaining demand; 2) expansion of demand; 3) demand forecasting; 4) demand control. As a result, the situation of intense competition between producers for consumers at a certain stage of development of the consumer society is poured into "marketing wars", which was recorded in the work of cult for marketers around the world by Trout, J. and Ries, A. (Trout, J., Ries, A., 1986)

However, not all so simple. The consumer is the "prize" for the winner in the "marketing war", but this does not mean that he fully controls the market and manufacturers. The very logic of the development of the consumer society quickly leads manufacturers to the need to seize the initiative and move on to demand management, i.e. behavior of their potential customers and even their future desires. In other words, in many markets, companies, in order to minimize costs, survive in competition and develop, it is necessary not only to satisfy the existing needs of consumers with their goods, but to "invent" new desires, create new market niches for promising products. This situation can be described by the phrase "We ourselves do not know what we will wish for tomorrow, but the manufacturing company is aware, it creates our desires."

According to its rational component, most modern goods and services resemble each other like twins. This is a simple explanation. The real innovation is a rarity, it is highly valued, but it costs the manufacturer too much. Sometimes it is so expensive that in conditions of high competitive risks it can be deadly for the company. An innovative product requires considerable investment, the price of launching a new product to the market increases, and the product life cycle shortens. Similar products are practically deprived of the opportunity to compete for the consumer, resorting to rational argumentation. The manufacturer simply needs to maintain an acceptable level of product quality in the market. Distinctive competitive advantages of goods are often formed at the level of additional value, i.e. in the form of psychological, emotional or symbolic advantages. It is more profitable for a manufacturer to work with goods at the level of manipulating their symbolic value than to create fundamentally new products or to go for high costs in order to maintain quality that is superior to competitors' products. It remains only to create a consumer who is satisfied with such a game, especially since in the consumer society he is prepared for this. So, J. Baudrillard fully revealed the symbolic essence of modern consumption, in which people are engaged in the social construction of their own identity through things-signs. (Clarke, D. B., 1997) Steven Jobs is the genius of modern business, but it is worth asking oneself: could millions of consumers manage without his products and at the same time not feel defective? In essence, they could. Jobs' cult and myth in its products means much more than its rational component, but it is this game that is being sold. In other words, Jobs ingeniously managed his consumers. An example from another product category: since when millions of consumers began to consider muesli as the best breakfast? Did they themselves decide so?

The above examples, despite the difference in product categories, are united by the automatism of consumer choice. In both cases, the producers did not lie to the consumer, but interfered with his model of choice and the model of behavior arising from it. This is the key to the effectiveness of modern marketing strategy - taking into account in the development of marketing decisions models of choice and consumer behavior of the target audience, the development of technologies to manage them.

Consumer choice occurs at the stage of correlating the price and value of the product. In modern marketing, price is defined as "the monetary expression of the value of a product, service, production factor in the exchange process", and value as "the significance (benefit) of a product, service, production factor for a consumer". (Kotler, P., Burton, S., Adam, S., Brown, L., Armstrong, G., 2007) In terms of the consumer society, the value of a product, as already mentioned, in some cases may not at all correspond to its rational qualities, but to have the status of high and even ultra-high psychological, emotional, symbolic consumer benefits. The price is actually an economic sacrifice that 
the consumer is ready (or not ready) to bring in order to acquire one or another value of the product, be it real or symbolic.

In economic psychology, sociology of management and marketing, many models of consumer choice are presented, some of which are used in marketing practice. So, one of the most common classifications of factors influencing consumer choice belongs to F. Krolar is a set of needs of SABONE (Securite - safety, Affection - attachment, Bien etre - comfort, Orgueil — pride, Nouveaute - novelty, Economic - economy). (Ratkus, K., Blinstrubas, A., 2009) At the same time, safety is associated with a sense of calm, durability, reliability of the selected product, guarantees of the time of its operation. Attachment, as a rule, expresses the internal connection between consumers and things, a kind of dependence on them (sometimes it is a habit of this or that thing). Comfort is the value of amenities purchased with the product. Pride satisfies the consumer's desire to purchase a product to distinguish oneself from the environment, to confirm or obtain a status different from others. Novelty is associated with the satisfaction of the desire for change, to update the surrounding reality and people. Savings, as the author of the classification emphasizes, with seemingly priority, often fade into the background, but can reinforce the sense of quality of the goods. Savings can be the main argument in the choice of a product, if the consumer has solvency problems and his actions are led by the desire to bring a minimum "economic sacrifice". This classification is simple, reasonable, can be used in practice at the stage of marketing design, the choice of topics and orientation, creative strategy of an advertising campaign. However, the real space of consumer behavior is not limited to the situation of choice. In addition, in the classification of J. Krolar explicitly takes into account the motivation of an "economic man," or a rational consumer, who makes a conscious choice. But in the practice of consumption, people sometimes do not realize why they buy and why, they make impulsive acquisitions, imitate others in consumption, enjoy the fact of consumption, can buy out of guilt, etc.

Popular approach to modeling consumer behavior in terms of the effects of consumption in the framework of non-functional demand. This approach is good only because it is freed from the limitations of the concept of "economic man" and shows that the real repertoire of consumer behavior in a situation of choice is much wider. The author of the approach H. Leibenstein points out three possible directions for consumer choice: the effect of joining the majority (or the bandwagon effect, the "general car effect", the choice of a product because of the desire to be like everyone else, keep up with others), the effect of "snob" (product choice, distinguishing the consumer from the crowd), the Veblen effect (or demonstrative consumption as a manifestation of a kind of pride, the choice of a product with such a high price that this in itself distinguishes the consumer from others). (Leibenstein, H., 1950)

One of the most authoritative marketing models for consumer choice was developed by F. Kotler as part of behaviorism. (Bagwell, L. S., Bernheim, B. D., 1996) Kotler, in the spirit of a behaviorist who witnessed consumption, saw the situation of consumer choice as a sequence of three blocks: a stimulus (for example, the impact of marketing-mix tools) - the signal processing in the black box of the consumer's mind - a reaction (like buying choice, dealer, brands or refuse to buy). This scheme clearly indicates to marketers at which points it is necessary to "push" on the consumer, i.e. purposefully use the marketing mix tools to correct his choice. However, this scheme does not say anything about the content of such "pressure". (Grundey, D., 2008.)

It is obvious that each author defines models of consumer behavior in accordance with his concept of consumption and consumer reactions. As a result, it receives models at any one point, for example, only at the stage of selection or only at the stage of reaction to marketing incentives. In the practice of marketing, it is important to present a coherent picture of consumer behavior, in order not only to adequately select the marketing mix tools for solving business goals, but also to predict consumer reactions. In addition, many practicing marketers are not inclined to delve into the theoretical subtleties, not everyone remembers who Baudrillard is, but on their own experience more than once were convinced that they are selling, for example, not lipstick, but a dream, illusion, i.e. not a thing, but a symbol - perfectly in the spirit of Baudrillard. (Tzokas, N., Saren, M., 1999) They need integral models of consumer behavior, as in some start for the formation of marketing strategies. Accordingly, these models should, if possible, take into account all modern theories describing the consumer at all stages of his actions in the process of purchasing products, accumulating and analyzing the experience of using them. 
Typically, the following aspects are taken into account in consumer behavior models: 1) the motives for choosing a product; 2) the level of awareness and independence of choice; 3) the level of consumer satisfaction with the product; 4) directions and opportunities to influence consumer choice through marketing, advertising incentives. (Jisana, T. K., 2014) In a kind of "model range", a rational consumer, an irrational (emotional) consumer, a motivated consumer, a conformist consumer, a consumer consuming (or zombied), an ethical consumer are presented. Of course, the boundaries of the models are conditional, these are abstractions that facilitate the understanding of the target audience and the prediction of its behavior, provide a vivid, informative picture of consumption in a particular category of goods and services, allow you to find effective tools for correcting the behavior of the audience. In addition, each consumer adheres to an average of two or three behaviors depending on the conditions of his life, the category of product and other factors. He can remain a rational consumer in the choice of real estate, but turn into an emotional one when it comes to low-price products, while adhering to the rules of the conformist consumer in choosing clothes. And only the ethical consumer model places high demands on the choice of product in almost all product categories - from real estate and cars to a cup of coffee in a restaurant.

\section{Marketing research of consumer characteristics of mass-produced goods}

Demographic, psychographic, behavioral and other criteria are commonly used to form consumer groups with homogeneous features (market segmentation). Consider consumer groups that can be formed on their basis, in relation to the acquisition of food products.

The information necessary for this is collected by the authors through a consumer survey conducted in the sales areas of stores in 2019.

When the market is segmented by geographic criterion, the market is divided into different geographical units: regions, cities, etc. This takes into account the density and population, climatic conditions, administrative divisions, remoteness from the enterprise, etc.

To determine the number of potential buyers of stores, often is used the method of determining the boundaries of zones of foot walking. People are more likely to go to the store for groceries, which is located closer to home, that is 10-15 minutes walk from their homes. This criterion met about $63 \%$ of respondents.

At the same time, integrated purchases of food products in hypermarkets are also popular (31\%). Despite the fact that their location may not be convenient (such outlets are rarely located in the zone of daily consumer routes), consumers go to them to reduce the number of visits to stores during the week. This is due to the high workload of consumers at work and their desire to minimize time spent on the routine tasks of daily food purchases.

This factor contributes to the emergence of consumers who purchase products via the Internet. This category of people is still small, because:

- people tend to see for themselves the qualitative characteristics of food products;

- online food products trading is organized in a relatively small number of outlets;

- Internet purchases are preferred by young people.

The most popular in the segmentation of the market are the demographic signs. At the same time, the market is divided based on the age of customers, family size and family life cycle, gender, income level, occupation, education, etc.

Describing the age structure of buyers of food products, it is possible to conclude that mainly people of middle age (30-50 years old) make purchases.

At the same time, young buyers to a greater extent rely on the image of the product, the activity of its advertising. When making a purchase, they tend to focus on their opinions, with little recourse to the help of sales consultants. When buying goods, middle-aged buyers pay attention to the maximum number of factors (price, quality, range, useful properties, etc.). When making a purchase, they may turn to the seller for advice, and they are not against providing them with additional services. People in old age begin to take more care of their health and, as a result, prefer to purchase products from domestic manufacturers, carefully checking the expiration dates. In addition, they are interested in cheaper products and a minimal amount of services due to limited financial opportunities. They will 
consult with sellers for a very long time for fear of making a mistake when buying and lack of communication.

It should also be noted that the age structure of buyers and the age structure of consumers of products are seriously different. The fact is that the purchase of food products for the whole family usually trust one of its members. Knowing the desires of his household, he chooses products, guided more by his experience and knowledge. In this regard, store personnel need to include in the assortment goods that are intended for all age groups (regardless of whether they buy goods on their own), but at the same time, forming approaches to work with customers, take into account the peculiarities of direct purchase customers. A vivid example is the implementation of products for small children. Parents make a purchase, knowing what kind of treats their child likes. At the same time, they pay attention to the factors of the health benefits of these products, which do not arouse any interest in children.

The size and life cycle of a family influence to a greater extent the purchase volume and its cost. According to the survey, $70 \%$ of respondents have families consisting of 3-4 people (mostly mother, father, child). At the same time, the larger the family of the buyer, the more carefully he approaches the distribution of the available finances among all the needs of the household. Needs are tightly ranked and more essential products are selected. They practically do not acquire "excess" goods, as compared with buyers, who take into account only their needs. In addition, if there are children in the family, then the buyer, when making a purchase, can go on infringing on his interests to please the child.

The role of shoppers in the store is often played by women. Their share in the total number of buyers is $62 \%$. They are housewives in families and, therefore, have a greater understanding of the food needs of the family and the need to replenish food stock. When making a purchase, they are more economical than men, study the information on the labels more carefully, and can make an impulsive purchase more often. In addition, they are more creative in their buying process, because they can quickly decide on the need to purchase a particular product. In a similar situation, a man will more strictly follow the previously drawn up purchase plan.

Income levels have the greatest impact on customers when they make purchases. When purchasing products, few and middle-income groups prefer high-quality, but inexpensive goods. Most often acquire consumer goods. They rarely buy product delicacies - on holidays and in order to "pamper yourself". Well-off and wealthy citizens with a purchase wish to receive the maximum amount of services, regardless of their value. Most of the purchases they make in prestigious shops aimed at serving the wealthy segments of the population (regardless of their location).

Occupation in relation to stores that sell food products, has a greater impact on the previous factor, i.e. on the financial condition of citizens. As a result, it determines the frequency, volume and cost of purchases made. That is, the higher the position in the organizational structure of a person, the more prestigious his work, the greater his earnings, which means:

- he goes to the store more often;

- he buys more goods;

- he has the opportunity to buy more expensive goods;

- he spend more money on food purchases.

The level of education characterizes buyers according to the level of readiness to make product choices and awareness of the properties of goods. The higher the level of education, the buyers make the purchase more competently, i.e. can justify their choice and clearly state their requirements for product quality and level of service in the store. Most of these buyers are aware of their rights and know how to protect them in case of unfair treatment of employees of the outlet.

Psychographic segmentation involves the formation of consumer groups based on their lifestyle and personality characteristics. When characterizing the way of life of consumers in terms of its influence on their behavior when buying food products, buyers' attitude to health is more important.

A consumer survey showed that most people (64\% of respondents) try to adhere to a healthy lifestyle as far as possible. This means that when choosing from two similar products, they will choose a product that has a greater positive impact on health (they seek to buy environmentally friendly products and refuse to purchase products containing genetically modified components). At the same 
time, if in the assortment of the store there are no such goods, they will choose another suitable product.

$27 \%$ of store buyers believe that you need to buy groceries that contribute to their healthy lifestyle. The absence of such goods in the assortment of the outlet leads to a refusal to purchase other similar products. The remaining 14\% of customers, when purchasing food, do not take into account the level of their impact on human health. Acquire goods, guided by their taste sensations and desires.

Personality features determine the immediate behavior of a person at the time of purchase. Thus, $41 \%$ of consumers are distinguished by their calm character, the desire to avoid extremes, and conservatism. These people have a well-formed opinion on products that is difficult for the seller to reverse during the sale of goods. They tend to acquire well-known products and rarely buy new items. They operate in the store often according to a predetermined plan.

At the time of purchase, $36 \%$ of buyers show the opposite behavior. They are impulsive, emotional, welcome change. They are relatively easy to make an impact and persuade them to purchase a particular product, as well as try a novelty. They openly express their feelings and are easily excited, therefore, when working with them, sales personnel should be especially careful in their statements and actions, because this can provoke them to an explosion of emotions that can be transmitted to surrounding buyers.

These are two extreme positions. The intermediate position is occupied by $20 \%$ of consumers. In their behavior, behavior patterns of the above-described personality types can occur in various combinations.

When segmenting the market, you can also resort to behavioral signs. In this case, consumers are divided into groups depending on the reason for making a purchase, the desired goods, the intensity of consumption, the level of loyalty, the status of the user, the level of readiness to purchase, and the reaction to the product.

Visiting food stores in most cases, of course, due to this reason for shopping as the need to replenish food stocks. This reason indicated $97 \%$ of respondents. A minor part of customers noted $(2 \%)$ that their arrival at the store necessitated the organization of a festive feast. In such a situation, consumers tend to buy food delicacies and products not included in the daily diet. In addition, they hope to get the highest quality goods, because strive to show themselves in the best light in front of their relatives and friends. The cost of goods purchased for a holiday may be slightly higher than the cost of goods purchased on a typical day.

An even smaller proportion of visitors noted the need to purchase goods on a trip as a reason for making a purchase. In this case, consumers tend to buy fast food products that will satisfy hunger on the road with minimal effort on the part of the buyer.

The benefits that consumers are looking for when buying, directly depend on the needs that govern the behavior of a person at this moment. If adhere to the theory of A. Maslow, then consumers can be divided according to their needs as shown in Table 1.

Table 1.

Dividing consumers according to their needs

\begin{tabular}{|c|l|l|l|}
\hline No. & \multicolumn{1}{|c|}{ Needs } & $\begin{array}{c}\text { Part of } \\
\text { respondents, } \\
\%\end{array}$ & \multicolumn{1}{|c|}{ Description } \\
\hline 1. & $\begin{array}{l}\text { Physiological } \\
\text { needs }\end{array}$ & $25 \%$ & $\begin{array}{l}\text { These consumers purchase goods essential for their physical } \\
\text { survival. The sought goods in this case are the quality and } \\
\text { price of the goods, i.e. consumers tend to buy goods that } \\
\text { allow them to fully satisfy the feeling of hunger, at the lowest } \\
\text { possible price. }\end{array}$ \\
\hline 2. & $\begin{array}{l}\text { Security } \\
\text { needs }\end{array}$ & $42 \%$ & $\begin{array}{l}\text { Such people seek to achieve stability, predictability of events } \\
\text { and to avoid such threats as illness, hunger, poverty, etc. } \\
\text { When buying goods, they hope to receive such benefits as: }\end{array}$ \\
\hline
\end{tabular}




\begin{tabular}{|c|c|c|c|}
\hline & & & $\begin{array}{l}\text { - product quality in terms of safety for health; } \\
\text { - quality of service, which allows minimizing the } \\
\text { level of inappropriate choice; } \\
\text { - cost savings, allowing to preserve the existing } \\
\text { lifestyle. }\end{array}$ \\
\hline 3. & Social needs & $23 \%$ & $\begin{array}{l}\text { The purchase of goods and their subsequent use, in the } \\
\text { opinion of these consumers, should facilitate the } \\
\text { establishment of attachment relationships with others in their } \\
\text { family and / or group. Seeking benefits: the ability to } \\
\text { communicate in a store with other people, the possibility of } \\
\text { organizing holidays and other similar events with the help of } \\
\text { goods. In any case, these people are looking for } \\
\text { communication and do everything possible to get this } \\
\text { opportunity. Purchased goods must meet the requirements of } \\
\text { the group of which the person wants to be a member. }\end{array}$ \\
\hline 4. & $\begin{array}{l}\text { Requirements } \\
\text { for respect }\end{array}$ & $7 \%$ & $\begin{array}{l}\text { These consumers believe that products should emphasize } \\
\text { reputation, status, and be prestigious. In this regard, the } \\
\text { sought-after benefits include high quality goods, a wide } \\
\text { range, high quality services, a large number of related } \\
\text { services, etc. }\end{array}$ \\
\hline 5. & $\begin{array}{l}\text { Needs for } \\
\text { self- } \\
\text { expression }\end{array}$ & $3 \%$ & $\begin{array}{l}\text { People who have a need for self-expression tend to buy } \\
\text { goods that allow them to show their abilities and talents in } \\
\text { front of their relatives and friends (in the case of food } \\
\text { products, these are often talents in the field of cooking, as } \\
\text { well as the opportunity to show the qualities of a hospitable } \\
\text { and hospitable host). Seeking benefits: maximum quality of } \\
\text { goods, novelty of goods. }\end{array}$ \\
\hline & TOTAL & $100 \%$ & \\
\hline
\end{tabular}

With regard to the intensity of consumption of products, this classification feature is not informative in relation to the aggregate of food products. The fact is that the volume and intensity of food consumption in general is determined by human physiology.

A completely different question - what kind of outlets do they visit? Less wealthy citizens tend to buy more goods on the market and in economy class stores, reducing the need to visit more expensive stores to a minimum. Wealthy citizens can afford to purchase products in any outlets.

The level of loyalty to the outlet allows you to assess the commitment of consumers to a particular seller of goods. A survey showed that buyers do not have clear preferences in visiting a particular outlet. The fact is that the assortment of stores includes similar products, and in the policy on working with clients there are no serious differences in stores. When choosing a store, consumers are more focused on the convenience of its location. Thus, among customers, $60 \%$ of respondents believe that they visit the store often. Moreover, as a reason for visiting, $84 \%$ note its convenient location, and not factors determining loyalty (quality, price, range, service, etc.)

User status characterizes the experience of people in purchasing goods. With respect to food products, the status of a user directly depends on his age - the older a person is, the more he has made purchases in his life, the more intelligent he can make the purchase process. From this point of view, almost all consumers are regular users.

If the status of the user as a visitor to a particular outlet is considered, then the majority of customers are regular users due to the fact that they have been living in the segment served by this enterprise for a long time. The share of newcomers is insignificant and is determined by the rate of construction of new homes in the geographical segment served by each store individually.

Describing the level of consumer readiness to make a purchase, it can be noted that it is high. Consumers are well aware of the properties of food products, therefore, as soon as they have a need for a product, they go to the store and make a purchase. 
Having carried out the characteristic features of consumer behavior according to various segmentation features, it is necessary to determine the most important of them. In authors opinion, when segmenting the market to retail outlets, such classification features as the age of buyers and their income level should be taken into account. All other segmentation criteria are somehow interconnected with the selected features. For example, the size of the family and its life cycle depend on the age of the buyer. The level of income is a consequence of occupation and education. At the same time, it itself affects the lifestyle of a person and the intensity of consumption.

\section{Conclusions, proposals, recommendations}

As a result of the research, the following conclusions were made:

1. Intensification of consumer behavior leads to negative social consequences associated with transformations in the value system, aggravating conflicts in society and DE structuring the system of social relations.

2. As for consumer behavior models, in the middle of the twentieth century, it became clear that in modeling consumer behavior there are not and cannot be definitive truths and schemes: these models develop together with the consumer society.

3. At the dawn of the consumer society, it was still possible to say that the demand or desires of consumers control the behavior of producers, forcing them to expand production or create new products that meet the rational needs.

4. Typically, the following aspects are taken into account in consumer behavior models: 1) the motives for choosing a product; 2) the level of awareness and independence of choice; 3) the level of consumer satisfaction with the product; 4) directions and opportunities to influence consumer choice through marketing, advertising incentives.

5. User status characterizes the experience of people in purchasing goods. With respect to food products, the status of a user directly depends on his age - the older a person is, the more he has made purchases in his life, the more intelligent he can make the purchase process. From this point of view, almost all consumers are regular users.

6. If the status of the user as a visitor to a particular outlet is considered, then the majority of customers are regular users due to the fact that they have been living in the segment served by this enterprise for a long time.

7. Describing the level of consumer readiness to make a purchase, it can be noted that it is high. Consumers are well aware of the properties of food products, therefore, as soon as they have a need for a product, they go to the store and make a purchase.

Based on the conclusions, the following proposals were made.

1. In authors opinion, when segmenting the market to retail outlets, such classification features as the age of buyers and their income level should be taken into account. All other segmentation criteria are interconnected with the selected features. For example, the size of the family and its life cycle depend on the age of the buyer. The level of income is a consequence of occupation and education. At the same time, it itself affects the lifestyle of a person and the intensity of consumption.

2. Marketing specialists should use user status to characterize the experience of people in purchasing goods. With respect to food products, the status of a user directly depends on his age - the older a person is, the more he has made purchases in his life, the more intelligent he can make the purchase process.

\section{References}

Ahmed, A. I., Uddin, M., 2004. Weber's perspective on the city and culture, contemporary urbanization and Bangladesh. Bangladesh e-journal of Sociology, 1(1), 7-8.

Bagwell, L. S., Bernheim, B. D., 1996. Veblen effects in a theory of conspicuous consumption. The American Economic Review, 349-373.

Bahr, H. M., Chadwick, B. A., 1985. Religion and family in Middletown, USA. Journal of Marriage 
and the Family, 407-414.

Baudrillard, J., 2001. System of things. Moscow: Rudomino.

Baudrillard, J., 2016. The consumer society: Myths and structures. Sage.

Baudrillard, J., Levin, C., 1981. For a critique of the political economy of the sign (Vol. 262). St. Louis: Telos press.

Clarke, D. B., 1997. Consumption and the city, modern and postmodern. International Journal of Urban and Regional Research, 21(2), 218-237.

Grundey, D., 2008. Experiential marketing vs. traditional marketing: Creating rational and emotional liaisons with consumers. The Romanian Economic Journal, 29(3), 133-151.

Jensen, O. B., 2006. 'Facework', flow and the city: Simmel, Goffman, and mobility in the contemporary city. Mobilities, 1(2), 143-165.

Jisana, T. K., 2014. Consumer behaviour models: an overview. Sai Om Journal of Commerce \& Management, 1(5), 34-43.

Kim, H. K., Pears, K. C., Capaldi, D. M., Owen, L. D., 2009. Emotion dysregulation in the intergenerational transmission of romantic relationship conflict. Journal of Family Psychology, 23(4), 585.

Kotler, P., Burton, S., Adam, S., Brown, L., Armstrong, G., 2007. Marketing. Pearson Education Australia.

Krohn, M. D., Massey, J. L., 1980. Social control and delinquent behavior: An examination of the elements of the social bond. The Sociological Quarterly, 21(4), 529-544.

Leibenstein, H., 1950. Bandwagon, Snob, and Veblen effects in the theory of consumers' demand. The quarterly journal of economics, 64(2), 183-207.

Marx, K., 2000. Selected writings, 2nd edition. Oxford University Press; 2nd edition.

Mitchell, W. C., 1910. The rationality of economic activity. Journal of Political Economy, 18(3), 197-216.

Ratkus, K., Blinstrubas, A., 2009. Aptarnavimo kokybė asmeniniame pardavime: slapto pirkejjo tyrimas. Ekonomika ir vadyba: aktualijos ir perspektyvos, (1), 217-223.

Roszkowska-Hołysz, D., 2013. Determinants of consumer purchasing behaviour/Uwarunkowania zachowań nabywczych konsumentów w świetle teorii zachowań konsumentów. Management, 17(1), 333-345.

Timothy, D. J., 2005. Shopping tourism, retailing and leisure. Channel View Publications.

Trout, J., Ries, A., 1986. Marketing warfare. New York: McGraw-Hill.

Tzokas, N., Saren, M., 1999. Value transformation in relationship marketing. Australasian Marketing Journal (AMJ), 7(1), 52-62.

Veblen T., 1953. The theory of the leisure class. New York: Mentor Books. 